\title{
Uji Aktivitas Antibakteri Ekstrak Daun Senduduk (Melastoma Affine D.Don) Terhadap Staphylococcus Aureus
}

\author{
Asiska Permata Dewi \\ Faculty of Faculty of Medicine and Health Sciences, Universitas Abdurrab, Indonesia \\ asiska.permata@univrab.ac.id
}

\begin{abstract}
This researh has already done inhibition test of ethanol extract in senduduk leaves to Staphylococcus aureus. Senduduk leaves have afficacy as a fever-lowering drugs, pain relief, to treat vaginal discharge, diarrhea, and can treat variety of wound infection. Infection of wound usually infected by bacteria Staphylococcus aureus. Aims of this research is to knows inhibition the ethanol axtract senduduk leaves (Melastoma affine D.Don) to Staphylococcus aureus. Extract suspended in Na CMC 0,5\%. Na CMC used as a negative control, klindamisin as a positive control, and ethanol extract of senduduk leaves with concentrations 20\%, 25\%, and 30\%. This research used diffusion method with disk paper. The result showed the average zone of inhibition at concentrations 20\%, 25\%, and 30\% is: 15,1 mm, 15,9mm, 20,5mm, whereas the positive control is $29,15 \mathrm{~mm}$. Based on the criteria for the interpretation of antimicrobial agents according to Coyle (2005), the diameter of inhibition zone concentration of $20 \%$, dan $25 \%$ are resistant ( $\leq 16 \mathrm{~mm}$ ), and the concentration of $30 \%$ including intermediate category.
\end{abstract}

Key words: Melastoma affine D. Don, Staphylococcus aureus, inhibition

\begin{abstract}
Abstrak Telah dilakukan penelitian uji aktivitas antibakteri ekstrak daun senduduk terhadap Staphylococcus aureus. Daun senduduk mempunyai khasiat sebagai obat penurun demam, pereda nyeri, mengobati keputihan, diare, luka yang disebabkan oleh infeksi bakteri ataupun jamur. Salah satu penyebab infeksi pada luka adalah Staphylococcus aureus. Tujuan penelitian ini adalah untuk mengetahui dan menghitung zona bening yang diperoleh dari ekstrak daun senduduk terhadap Staphylococcus aureus. Ekstrak disuspensikan dalam Na CMC 0,5\%. Ekstrak daun senduduk yang diuji adalah pada konsentrasi 20\%, 25\% dan 30\%, klindamisin sebagai kotrol positif, dan Na CMC sebagai control hambat konsentrasi $20 \%$ dan 25\% termasuk kategori resisten $(\leq 16 \mathrm{~mm})$, dan konsentrasi $30 \%$ termasuk kategori intermediet 17-20mm.negatif. Penelitian ini menggunakan metode difusi agar dengan disk (cakram). Hasil penelitian didapatkan rata-rata zona hambat pada konsentrasi 20\%, 25\% dan 30\% adalah: $15,1 \mathrm{~mm}, 15,9 \mathrm{~mm}, 20,5 \mathrm{~mm}$, sedangkan pada kontrol positif sebesar 29,15 mm. Berdasarkan kriteria interpretasi untuk agen antimikroba menurut Coyle (2005), diameter zona
\end{abstract}

Kata kunci: Melastoma affine D. Don, Staphylococcus aureus, daya hambat

\section{Pendahuluan}

Dengan berkembangnya ilmu pengetahuan dan teknologi pada dekade ini, penggunaan obat tradisional di tengah masyarakat tidak bisa dikesampingkan begitu saja. Justru, penggunaan obat tradisional dan obat modern saling melengkapi satu sama lain. Masyarakat dapat memperoleh tumbuhan obat tradisional ini di alam, dapat ditanam sendiri sebagai tanaman obat keluarga (TOGA), dan dapat diramu sendiri. (simanjuntak, 2008).

Diantara tanaman obat tradisional yang banyak terdapat di alam, tumbuhan senduduk (Melastoma affine D. Don) dari suku Melastomataceae adalah salah satu tanaman yang banyak digunakan untuk pengobatan. Senduduk merupakan tanaman yang tumbuh liar dan dapat betahan hidup pada tanah yang kering dan tidak subur. Kandungan kimia daun senduduk yang telah diketahui antara lain flavonoid, tanin, saponin, glikosida dan steroida atau triterpenoida (Hidayat dan Rodame, 2015).

Tumbuhan senduduk ini berkhasiat sebagai obat antipiretik (penurun demam), analgesik (pereda nyeri), diuretik (peluruh air seni), mengatasi keputihan, diare, dan dapat mengobati berbagai jenis luka 
JOPS (Journal Of Pharmacy and Science)

Vol 3 No 1 Desember 2019

tersayat. Infeksi luka umumnya disebabkan oleh Staphylococcus aureus. Hasil penelitian yang dilakukan oleh peneliti sebelumnya menunjukkan bahwa ekstrak etanol daun senduduk dengan menggunakan metode dilusi mempunyai KHM (Konsentrasi Hambat Minimum) pada konsentrasi 2\% terhadap bakteri Staphylococcus aureus, dan pada bakteri Escherichia coli dengan konsentrasi 3\% (Kusumowati et al., 2014).

Luka merupakan suatu gangguan dari kondisi normal pada kulit. Luka pada kulit merupakan penyakit paling umum yang terjadi pada orang-orang dari segala usia. Sebagian masyarakat mempercayai pengobatan luka secara medis, tetapi sebagian yang lain masih menggunakan pengobatan secara tradisional dan turun temurun memanfaatkan tumbuhan alam. Secara umum, masyarakat masih banyak menggunakan daun senduduk sebagai obat luka infeksi dengan cara mengolesi daun segar atau daun kering yang digiling halus pada bagian kulit yang luka.

Kandungan senyawa metabolit sekunder dalam tumbuhan senduduk yang sudah diketahui antara lain saponin, flavonoid, tanin, glikosida, dan steroid atau triterpenoid. Golongan flavonoid memunjukkan aktivitas mengurangi atau menurunkan kadar kolesterol, dan sebagai antimikroba Golongan saponin memiliki efek sebagai antifungi, menghambat aktivitas otot polos. Senyawa tanin dimanfaatkan sebagai adstringen dan dimanfaatkan sebagai antidiare, menghentikan pendarahan, mencegah peradangan, antidotum keracunan logam berat (Hanani, 2015).

Pada manusia bakteri Staphylococcus aureus menyebabkan berbagai macam penyakit infeksi antara lain infeksi pada kulit, seperti bisul dan furunkulosis. Infeksi yang lebih serius seperti mastitis, pneumonia, flebitis, infeksi saluran urin, dan meningitis. Selain itu, Staphylococcus aureus juga menyebabkan infeksi nosocomial terhadap luka pasca operasi di rumah sakit. Staphylooccus aureus juga dapat menyebabkan keracunan makanan akibat enterotoksin yang dihasilkannya dan menyebabkan sindrom renjat toksik akibat pelepasan super antigen ke dalam aliran darah (Radji, 2010).

Klindamisin adalah antibiotik golongan aminoglikosida yang bekerja dengan cara menghambat sintesis protein bakteri yang rentan pada tingkat ribosom 50S. Efek terapeutik, bersifat bakterisidal atau bakteriostatik, bergantung pada kerentanan dan konsentrasi. Aktif terhadap bakteri kokus gram positif aerobik termasuk Staphylococcus, Streptococcus pnoumoniae, namun bukan Enterococcus. Klindamisin mempunyai aktivitas yang baik terhadap bakteri anaerobik yang menyebabkan vaginosis bakterial, termasuk Bacteroides fragilis sp, Gardinerella vaginallis, Mobiluncus sp, Mycoplasma hominus, dan Corinabacterium.

Efek terapeutik, bersifat bakterisidal atau bakteriostatik, bergantung pada kerentanan dan konsentrasi. Aktif terhadap bakteri kokus gram positif aerobik termasuk Staphylococcus, Streptococcus pnoumoniae, namun bukan Enterococcus. (Deglin dan Vallerand, 2004). Klindamisin berpenetrasi dengan baik ke dalam sebagian besar jaringan, kecuali ke otak. Klindamisin dimetabolisme oleh hati, dan bentuk aktif obat ini serta metabolitnya yang juga aktif dieksresi dalam empedu dan urine. Waktu paruhnya 2,5 jam pada individu normal, dan meningkat hingga 6 jam (Katzung, 2012). 
JOPS (Journal Of Pharmacy and Science)

Vol 3 No 1 Desember 2019

\section{Metode Penelitian}

Penelitian ini adalah penelitian deskriptif secara in-vitro dengan mengukur daya hambat ekstrak etanol daun senduduk pada konsentrasi 20\%, 25\%, dan 30\% terhadap Staphylococcus aureus dengan pembanding klindamisin.

\section{Sampel}

Sampel yang digunakan pada penelitian ini adalah daun yang berwarna hijau dalam keadaan segar yang diambil di Desa Lipat kain kecamatan Kampar Kiri, Pekanbaru, Riau.

\section{Alat dan Bahan}

Alat yang digunakan dalam penelitian ini adalah alat-alat gelas, kawat ose, spritus, timbangan, rotary evaporator, incubator, oven, daun senduduk, etanol, Na CMC, MHA, strain murni Staphylococcus aureus, disk klindamisin (sebagai kontrol positif), etanol 96\%, $\mathrm{H}_{2} \mathrm{SO}_{4}, \mathrm{BaCl}_{2} 2 \mathrm{H}_{2} \mathrm{O}$ 1,175\%, dan $\mathrm{NaCl}$ fisiologis, darah.

\section{Pembuatan Simplisia}

Sampel yang digunakan adalah daun senduduk segar kemudian dilakukan sortasi basah, yaitu memisahkan daun dari kotoran atau bahan asing yang menempel seperti debu, tanah, dan kotoran lainnya. Kemudian dicuci dengan air bersih dan daun senduduk dipotong-potong halus. Selanjutnya sampel dikering anginkan. Lalu dilakukan sortasi kering, yaitu bagian pengotor yang masih ada dibersihkan.

\section{Pembuatan Ekstrak}

Simplisia daun senduduk ditimbang sebanyak 500 gram, kemudian direndam dengan etanol 96\%, selama 3 - 4 hari sambil sekali -kali diaduk. Proses maserasi atau perendaman diulangi sebanyak 3 kali. Kemudian maseratnya dikumpulkan, dan pelarut diuapkan dengan rotary evaporator hingga didapatkan ekstrak kental.

\section{Pembuatan Media}

Ditimbang (38 gram untuk $1000 \mathrm{ml}$ ) media MHA (Mueller Hinton Agar) dimasukkan ke dalam erlenmeyer $250 \mathrm{ml}$, ditambahkan akuades $100 \mathrm{ml}$ lalu dipanaskan hingga larut secara sempurna, ditutup dengan kapas. Media disterilkan di dalam autoclave pada suhu $121^{\circ} \mathrm{C}$ selama 15 menit, setelah dikeluarkan dari autoclave diamkan media beberapa saat sampai media tidak terlalu panas hingga suhu $40^{\circ} \mathrm{C}-50^{\circ} \mathrm{C}$, kemudian ditambahkan $5 \mathrm{ml}$ (5\%-8\%) darah ke dalam media, kocok hingga homogen, tuangkan ke cawan petri.

\section{Pengujian Daya Hambat}

Dengan menggunakan kapas lidi steril, suspensi bakteri dioleskan pada permukaan media hingga merata. Disk klindamisin diambil letakkan pada permukaan media, diberi tekanan, sebagai kontrol positif. Selanjutnya diambil kertas disk kosong sebanyak 4 buah diletakkan pada permukaan media, diberi tekanan, kemudian ditetesi suspensi Na CMC $2 \mu$ sebagai kontrol negatif, ekstrak etanol daun senduduk dengan konsentrasi $20 \%, 25 \%$ dan $30 \%$. Selanjutnya, diinkubasi selama $24-48$ jam pada suhu $37^{\circ} \mathrm{C}$ di dalam inkubaktor. Selanjutnya diukur diameter zona hambat yang terbentuk. 
JOPS (Journal Of Pharmacy and Science)

Vol 3 No 1 Desember 2019

\section{Analisis Data}

Data yang diperoleh pada uji daya hambat ekstrak daun senduduk terhadap Staphylococcus aureus dengan pembanding klindamisin disajikan dalam bentuk tabel dan dianalisis secara deskriptif.

\section{Hasil dan Pembahasan}

Penelitian ini bertujuan untuk mengetahui dan menghitung zona hambat ekstrak etanol daun senduduk terhadap Staphylococcus aureus. Setelah sampel dikumpulkan, kemudian sampel dijadikan simplisia. Simplisia daun senduduk direndam dengan etanol 96\%, selama 3 - 4 hari sambil sekali-kali diaduk. Proses maserasi atau perendaman diulangi sebanyak 3 kali. Kemudian maseratnya dikumpulkan, dan pelarut diuapkan dengan rotary evaporator hingga didapatkan ekstrak kental.

Media yang digunakan dalam penelitian ini adalah media Mueller Hinton Agar (MHA) karena media ini telah direkomendasikan oleh FDA dan WHO untuk tes antibakteri terutama bakteri aerob dan fakulatif aerob. Media ini mengandung sulfonamida, trimethoprin, dan inhibitor tetrasiklin yang rendah serta memberikan pertumbuhan patogen yang memuaskan (Acumedia, 2004). Penambahan darah pada media dikarenakan bakteri Staphylococcus aureus tersebut tumbuh subur pada agar darah.

Kontrol positif yang digunakan adalah klindamisin, karena dapat menghambat bakteri gram positif termasuk Staphylococcus aureus (Deglin dan Vallerand, 2004). Na CMC digunakan sebagai kontrol negatif, dan digunakan sebagai pelarut ekstrak etanol daun senduduk. Larutan ini tidak memiliki aktivitas antibakteri dan sangat berperan dalam mendispersikan ekstrak daun senduduk agar terlarut dengan baik (Kusumowati et al., 2014) .

Konsentrasi ekstrak yang dibuat adalah tiga konsentrasi yaitu 20\%, 25\% dan 30\%. Tujuan variasi konsentrasi ini untuk melihat perbedaan daya hambat dengan berbagai perbedaan konsentrasi. Pengujian dilakukan lima kali pengulangan yang bertujuan untuk memperoleh hasil yang lebih akurat. Diameter rata-rata zona hambat pada konsentrasi $20 \%$, 25\% dan 30\% adalah 15,1 mm, 15,9 mm, dan 20,05 mm. Rata-rata zona hambat pada kontrol positif sebesar 29,15 mm. Kontrol negatif Na CMC tidak ada memberikan daya hambat karena zona hambatnya $6 \mathrm{~mm}$ yang merupakan diameter disk (Tabel 1).

Berdasarkan hasil di atas, konsentrasi 30\% daya hambatnya lebih besar dibandingkan konsentrasi $20 \%$ dan 25\%. Hal ini disebabkan pada konsentrasi 30\% ekstraknya lebih kental sehingga komposisi kandungan metabolit sekunder lebih banyak dibandingkan konsentrasi 20\% dan 25\%. Berdasarkan kriteria interpretasi untuk agen antimikroba menurut Coyle (2005), diameter zona hambat konsentrasi $20 \%$ dan 35\% termasuk kategori resisten ( $\leq 16 \mathrm{~mm}$ ), dan konsentrasi 30\% termasuk kategori intermediet 17-20 mm. Daun senduduk memiliki kandungan metabolit sekunder diantaranya senyawa flavonoid, polifenol, tanin, dan saponin. Pada daun senduduk senyawa flavonoid memiliki aktivitas antibakteri karena dapat membentuk senyawa kompleks dengan protein yang terdapat pada dinding sel maupun protoplas sel (Hertiani et al., 2003). 
JOPS (Journal Of Pharmacy and Science)

Vol 3 No 1 Desember 2019

Tabel 1. Hasil uji daya hambat etanol ekstrak daun senduduk (Melastoma affine D. Don) terhadap Staphylococcus aureus.

\begin{tabular}{llcccccc}
\hline No & Sampel & \multicolumn{5}{c}{ Diameter zona hambat (mm) } & Rata-rata \\
\cline { 3 - 7 } & & I (mm) & II (mm) & II $(\mathrm{mm})$ & IV (mm) & V (mm) & (mm) \\
\hline 1 & Konsentrasi 20\% & 17 & 15 & 15,5 & 15 & 13 & 15,1 \\
2 & Konsentrasi 25\% & 14 & 15 & 15 & 19,75 & 15,75 & 15,9 \\
3 & Konsentrasi 30\% & 20 & 20 & 18 & 22,25 & 20 & 20,05 \\
4 & Klindamisin & 24,75 & 29,25 & 31 & 30,75 & 30 & 29,15 \\
5 & Na CMC & 6 & 6 & 6 & 6 & 6 & 6 \\
\hline
\end{tabular}

\section{Kesimpulan}

Setelah dilakukan penelitian, dapat disimpulkan bahwa rata-rata zona hambat ekstrak etanol daun senduduk terhadap S. aureus pada konsentrasi 20\%, 25\% dan 30\% adalah 15,1 mm, 15,9 mm dan 20,05 $\mathrm{mm}$. Hal ini menunjukkan bahwa ekstrak daun senduduk dapat menghambat pertumbuhan bakteri $\mathrm{S}$. Aureus. Semakin tinggi kosentrasi ekstrak, maka daya hambat yang ditimbulkan juga semakin besar.

\section{Ucapan Terima Kasih}

Terimakasih penulis ucapkan kepada Prodi D III Analis Farmasi dan Makanan yang telah memfasilitasi dalam penelitian ini, serta mahasiswa yang turut serta membantu dalam pelaksanaan penelitian ini.

\section{Referensi}

Acumedia. 2004. Mueller Hinton Agar. P1 7101. Rev 02.11/14/04

Coyle, M. B. 2005. Manual of Antimicrobial Susceptibility Testing. American Society for Microbiology.

Deglin, J.H, dan Vallerand, A.H. 2004. Pedoman Obat Untuk Perawat. Jakarta: Penerbit Buku Kedokteran

Hanani, E. 2015. Analisis fitokimia. Jakarta: EGC

Hertiani T., Palupi, I.S., Sanliferianti, \& Nurwindasari, H.D. 2003. Uji Potensi Antimikroba terhadap $S$. Aureus. E. coli. Shigella dysentriae, dan Candida albicans dari Beberapa Tanaman Obat Tradisional untuk penyakit infeksi. Pharmacon. Vol. 4. No. 2. UMS. Surakarta.

Hidayat, R.S., dan Rodame M.N. 2015. Kitab Tumbuhan Obat. Jakarta: Agriflo, Penerbangan Swadaya Grup.

Kusumowati, I.T.D, Melanisa, R dan Prasetyawan, A. 2014. Daya Antibakteri Ekstrak Etanol Daun Senggani (melastoma affine D.Don). Biomedika, Volume 6. Nomor 2.

Radji, M. 2010. Buku Ajar Mikrobiologi : Panduaan Mahasiswa Farmasi dan Kedokteran. Jakarta. EGC

Simanjuntak, M. R. 2008. Ekstraksi dan Fraksinasi Komponen Ekstrak Daun Tumbuhan Senduduk (Melastoma malabathrium. L) serta Pengujian Efek Sediaan Krim Terhadap Penyembuhan Luka Bakar. Skripsi. Universitas Sumatra Utara. Medan 